\title{
PENDAPATAN BUKAN PADI BANTU PESAWAH KELUAR DARIPADA KEMISKINAN LEBIH CEPAT
}

\author{
Siti Hadijah Che Mat ${ }^{1+}$, Salmah Sathiman ${ }^{2}$ dan Fatimah Hamid ${ }^{3}$ \\ ${ }^{1}$ Pusat Pengajian Ekonomi, Kewangan dan Perbankan \\ Universiti Utara Malaysia \\ ${ }^{2,3}$ Institut Tadbir Awam Negara (INTAN) \\ Jabatan Perkhidmatan Awam Malaysia \\ +Corresponding author: hadijah@uum.edu.my
}

\begin{abstract}
Petani dan pertanian sering dikaitkan dengan kemiskinan. Petani padi antara mereka yang mempunyai pendapatan yang rendah. Justeru, kerajaan mencadangkan agar mereka terlibat dalam aktiviti ekonomi tambahan yang dapat memberikan pulangan yang tinggi. Sehubungan itu, objektif artikel ini adalah untuk mengetahui struktur pendapatan pesawah dan aktiviti ekonomi yang berjaya meningkatkan pendapatan pesawah serta tempoh masa yang dapat disingkatkan sekiranya pesawah mempunyai pendapatan lain selain daripada pendapatan padi. Sampel kajian ialah pesawah di IADA KETARA. Soal selidik telah diedarkan kepada 353 orang pesawah. Kajian mendapati majoriti pesawah (83.3\%) berada dalam kategori $B 40$. Hanya 16.4\% dalam kategori M40 serta hanya seorang dalam kategori T20. Seramai $64.6 \%$ pesawah terlibat dalam aktiviti ekonomi lain selain padi bagi meningkatkan pendapatan. Keputusan kajian juga mendapati pesawah yang terlibat dalam pelbagai aktiviti ekonomi tambahan yang lain lebih cepat untuk keluar daripada kepompong kemiskinan berbanding dengan mereka yang tidak mempunyai pendapatan daripada sumber aktiviti tambahan yang lain. Sebagai contoh, jika pertumbuhan pendapatan pesawah adalah sebanyak 5\%, purata masa yang diambil untuk keluar daripada kepompong kemiskinan bagi mereka yang miskin adalah selama 14.10 tahun sekiranya mereka memiliki pendapatan daripada sumber padi sahaja manakala masa yang diperlukan adalah lebih pendek iaitu 7.82 tahun bagi mereka yang mempunyai sumber pendapatan padi dan bukan padi. Bagi pesawah yang mempunyai pendapatan padi dan pendapatan bukan padi, mereka dijangka dapat menjimatkan masa untuk bebas daripada kemiskinan selama 6.28 tahun (14.10 tahun tolak 7.82 tahun) berbanding dengan mereka yang tidak mempunyai pendapatan daripada sumber bukan padi. Peningkatan produktiviti melalui pengembelingan tenaga muda dan penggunaan teknologi serta penglibatan aktif pihak kerajaan dan swasta adalah perlu bagi meningkatkan pendapatan dan kesejahteraan petani padi.
\end{abstract}

Kata kunci: Kemiskinan; pendapatan bukan padi.

JEL Codes: I3

Received 15 September 19. Revised 9 January 20. Accepted 10 January 20.

\section{Pengenalan}

Pertanian adalah tulang belakang bagi kebanyakan penduduk di luar bandar. Namun terdapat juga petani di luar bandar yang mempelbagaikan aktiviti ekonomi mereka yang tidak terhad kepada aktiviti pertanian sahaja (World Development Report, 2008, hlmn. 204). Di Indonesia, peningkatan pertumbuhan yang agresif dalam aktiviti bukan pertanian di luar bandar bermula sejak krisis kewangan 1997 (dari 30\% pada tahun 1990 kepada 40\% pada tahun 1995) sebelum jatuh pada tahun 2003. Di Bangladesh, aktiviti bukan pertanian di luar bandar meningkat pada kadar $0.7 \%$ setahun semenjak 1990 -an sementara aktiviti pertanian meningkat pada kadar $0.1 \%$ (Fields, 1994; Karp, 2007). Lanjouw (2000) membuktikan peranan yang dimainkan oleh sektor bukan pertanian kepada pengurangan kemiskinan di luar bandar melalui kajian terhadap isi 
rumah di Ecuador. Hasil kajian beliau menunjukkan sektor bukan pertanian telah menyumbang sebanyak $40 \%$ kepada pendapatan di luar bandar.

Menurut De Janvry (1981), upah daripada membuat kerja sambilan di luar bandar selalunya menjadi pelengkap kepada ketidakcukupan pengeluaran pertanian dalam memastikan keperluan penggunaan isi rumah terus dinikmati. Menurut kajian De Janvry, Sadoulet, dan Zhu (2005) di China, 72\% daripada isi rumah di luar bandar mempunyai pendapatan bukan pertanian. Pendapatan bukan pertanian bukan sahaja menyerap lebihan buruh di luar bandar, malah yang lebih penting ia boleh memperbaiki kualiti hidup di luar bandar. Bagi negara Amerika Latin seperti Ecuador, sektor bukan pertanian merupakan sektor terpenting dalam usaha mengurangkan kemiskinan; kemiskinan berkurangan apabila sumbangan daripada sektor bukan pertanian kepada jumlah pendapatan meningkat (Lanjouw, 1998). Begitu juga di Afrika Timur, disebabkan oleh teknologi yang kurang di dalam sektor pertanian, peningkatan jumlah penduduk yang mendadak dan kekurangan tanah menjadi penyebab perlunya sektor bukan pertanian dibangunkan untuk mengurangkan kemiskinan dan memperbaiki jaminan makanan (Heyer \& Campbell, 1999). Kesan jangka masa pendek pendapatan bukan pertanian di luar bandar terhadap jaminan makanan isi rumah petani adalah jelas. Pendapatan bukan pertanian juga merupakan sumber bagi isi rumah menyimpan (menabung) untuk membeli keperluan semasa dalam kesusahan (Barrett, Reardon, \& Webb, 2001).

Di Malaysia, kajian oleh Corner (1981) di Lembaga Kemajuan Pertanian Muda Kedah mendapati perlunya penglibatan dalam pekerjaan bukan pertanian sebagai strategi anti kemiskinan. Pendapatan bukan berasaskan pertanian adalah seperti petani terlibat dalam sektor perkhidmatan, perniagaan, berkhidmat dengan sektor kerajaan mahupun swasta, dan mungkin juga pemberian daripada anak-anak dan pencen. Shand (1987) melakukan kajian di kawasan pembangunan pertanian Kemubu, Kelantan untuk meneliti faktor-faktor penting yang mempengaruhi agihan sumber tenaga kerja di sektor pertanian dan bukan pertanian. Beliau mendapati bahawa penggunaan tenaga kerja isi rumah dalam kalangan petani telah berkurangan disebabkan oleh penjenteraan, dan lebihan tenaga kerja ini boleh dialirkan dengan mencipta lebih banyak pekerjaan dalam pertanian dan bukan pertanian. Penglibatan petani dalam aktiviti bukan pertanian dapat membantu meningkatkan pendapatan dan seterusnya membantu mereka yang miskin keluar daripada kepompong kemiskinan. Dalam penyelidikan mereka di Kelantan, Shand dan Chew (1983) mendapati bahawa pekerjaan bukan pertanian adalah signifikan kepada isi rumah petani. Majoriti petani di Kemubu didapati mempunyai pekerjaan bukan pertanian untuk menambah pendapatan walaupun mereka memiliki taraf hidup yang sederhana.

Industri penanaman padi sering berhadapan dengan pelbagai cabaran walaupun mendapat perhatian Kerajaan. Antaranya ialah isu kemiskinan dalam kalangan pesawah. Kajian oleh Norsida dan Sayiya (2009) mendapati bahawa lebih kurang 39\% daripada pesawah merupakan pesawah sepenuh masa dan pendapatan mereka bergantung kepada hasil padi. Secara puratanya, pesawah menerima pendapatan RM1,400 sebulan (Siti Badariah \& Mohd Rosli, 2016). Kajian mereka juga mencadangkan supaya pengiraan pendapatan sebenar pesawah perlu dilihat secara keseluruhan dengan mengambil kira pendapatan daripada aktiviti ekonomi lain. Bagi meningkatkan pengeluaran padi dan membantu pesawah, kerajaan menyediakan pelbagai bentuk subsidi dan insentif kepada pesawah untuk mengurangkan bebanan kos yang ditanggung (Ahmad Zubir \& Chamhuri, 2012).

Oleh itu, objektif penulisan ini adalah untuk menganalisis struktur pendapatan dan kesan pelaksanaan ekonomi tambahan atau aktiviti bukan pertanian terhadap pendapatan pesawah 
serta menganalisis tempoh masa yang boleh disingkatkan untuk keluar daripada kepompong kemiskinan dalam kalangan pesawah. .

\section{Kajian Lepas}

Di Malaysia, industri penanaman padi sering dikaitkan dengan kemiskinan semenjak kemerdekaan. Pada tahun 1970an, 60\% daripada pesawah di KADA dan MADA tergolong dalam kumpulan miskin (Mohd Rashid \& Mohd Dainuri, 2013). Walaupun berhadapan dengan pelbagai cabaran, namun sektor penanaman padi merupakan sektor yang penting kerana ia bukan setakat melibatkan dasar keselamatan makanan, malah ia merupakan aspek kestabilan sosial dan politik (Fatimah, Mohd Fauzi, \& Mohd Khanif, 2010, dalam Ahmad Zubir et al., 2012). Ini kerana hampir 0.3 juta penduduk Malaysia merupakan pesawah dan mereka adalah antara kumpulan sasar bagi program kemiskinan (Siti Badariah \& Mohd Rosli, 2016).

Isu kemiskinan masih terus membelenggu pesawah. Kajian di MADA menunjukkan jumlah pendapatan yang diperolehi oleh pesawah adalah rendah iaitu sebanyak RM2,527 sebulan berbanding dengan pendapatan minimum negara sebanyak RM6,958 sebulan (Khazanah Research Institute, 2019). Kajian terdahulu oleh Siti Hadijah, Ahmad Zafarullah, dan Mukaramah (2012) mendapati bahawa petani terlibat dengan pelbagai aktiviti ekonomi yang lain bagi kestabilan dan peningkatan pendapatan untuk ahli keluarga. Melakukan aktiviti tambahan seperti aktiviti bukan pertanian dalam kalangan petani juga mampu meningkatkan pendapatan petani (Siti Hadijah, Nor Aznin, \& Ahmad Zafarullah, 2012; Siti Hadijah \& Roslan, 2010)).

Menurut Lanjouw dan Lanjouw (2001), aktiviti bukan berasaskan ladang berperanan mewujudkan peluang pekerjaan di luar bandar dan ia secara tidak langsung menyumbang kepada pendapatan serta dalam masa yang sama mengurangkan migrasi perduduk dari luar bandar ke bandar. Aktiviti bukan berasaskan ladang ini merujuk kepada aktiviti ekonomi luar bandar kecuali pertanian, penternakan, perikanan, dan pemburuan. Ia melibatkan aktiviti seperti perkhidmatan, perniagaan dan pengangkutan, pembinaan dan pelombongan, dan pembuatan. Penemuan ini turut disokong oleh Norsida dan Sadiya (2009) yang mendapati bahawa penggabungan pendapatan daripada aktiviti berasaskan ladang dan bukan berasaskan ladang dapat menambah pendapatan pesawah berbanding jika mereka hanya bergantung kepada satu sumber sahaja. Mereka mendapati bahawa $40 \%$ daripada pendapatan sepenuh masa pesawah MADA disumbangkan oleh pendapatan aktiviti bukan berasaskan ladang. Kajian oleh Siti Hadijah, Ahmad Zafarullah, dan Mukaramah (2012) dalam kalangan petani yang berada di luar bandar di negeri Kedah menunjukkan pendapatan daripada aktiviti bukan berasaskan ladang menyumbang satu pertiga daripada jumlah pendapatan isi rumah petani. Penemuan ini turut disokong oleh Radin Firdaus et al. (2014) yang mencadangkan supaya aktiviti bukan pertanian ditingkatkan bagi mengurangkan kebergantungan kepada padi. Pendapatan bukan pertanian dilihat sebagai salah satu penentu kepada pendapatan pesawah. Melalui hasil pendapatan bukan pertanian yang diperolehi, taraf hidup pesawah akan terjamin sekiranya sumber pendapatan utama (padi) terjejas.

\section{Metodologi}

Kajian ini melibatkan 353 orang pesawah iaitu 10\% daripada keseluruhan jumlah penanam padi di IADA KETARA. Pada tahun 2016, IADA KETARA merupakan salah sebuah jelapang padi negara yang menghasilkan 50,438 metrik tan padi bersih negara iaitu $2.66 \%$ daripada pengeluaran padi negara (MOA, 2017). IADA KETARA juga merupakan jelapang yang mempunyai purata hasil bersih kedua tertinggi antara jelapang iaitu $5.17 \mathrm{mtan} / \mathrm{ha}$. Selain itu, IADA KETARA juga meletakkan sasaran pengeluaran sebanyak 6 mtan sehektar dalam 
tempoh RMKe11 (2016-2020) dan meningkatkan pendapatan pesawah kepada RM2,500 sebulan.

Nasi merupakan makanan ruji bagi 31 juta orang penduduk Malaysia. Ia merupakan sumber karbohidrat yang membekalkan tenaga kepada manusia. Maka industri penanaman padi mendapat perhatian utama dan dilindungi melalui kawalan harga, subsidi input, dan stok penimbal (Khazanah Research Institute, 2019, hlmn. 10) walaupun ia menyumbang hanya 2.3\% (RM2.4b) daripada keseluruhan jumlah Keluaran Dalam Negara (GDP) pada tahun 2016 yang berjumlah sebanyak RM1,196.4 billion.

Malaysia merupakan negara pengimport beras. Hanya 70\% sahaja daripada keperluan negara dikeluarkan oleh negara (Khazanah Research Institute, 2019). Baki keperluan diimport dari negara lain seperti Thailand, Vietnam, dan Pakistan (Farah Hanim, Nurul Nazihah, \& Norhaslina, 2017). Krisis kenaikan harga beras dunia yang berlaku pada akhir 2007 - 2008 mencetuskan rasa panik kepada negara pengimport beras (FAO, 2010: 15, 2011). Pada masa tersebut, harga beras Thai meningkat daripada $\$ 335$ per ton ke $\$ 1,000$ per ton dalam tempoh enam bulan (September 2017 - April 2008). Keadaan ini menyedarkan negara tentang betapa pentingnya padi terus ditanam di dalam negara kerana ia merupakan tanaman strategik dan bagi menjamin keselamatan makanan negara (Mohd Rashid \& Mohd Dainuri, 2013).

Sehingga tahun 2017, Malaysia mempunyai seluas 685,548 hektar kawasan bertanam padi (MOA, 2018). Daripada jumlah tersebut, seluas 426,249 hektar (62.18\%) padi ditanam di 12 kawasan jelapang dan is menyumbang sebanyak $75.18 \%(1,245,000 \mathrm{mt})$ kepada pengeluaran beras negara. Tiga kawasan jelapang yang mencatatkan pengeluaran padi bersih tertinggi ialah Lembaga Kemajuan Pertanian Muda (MADA) sebanyak 50.84\%. Lembaga Kemajuan Pertanian Kemubu (KADA) dan Kawasan Pembangunan Pertanian Bersepadu (IADA) Kerian masing-masing menyumbang $12.55 \%$ dan $10.59 \%$.

\section{Data Kajian}

Untuk kajian ini, pemilihan sampel dibuat secara rawak yang mewakili blok penanaman. Pengumpulan data dilaksanakan dalam bulan Januari - April 2018. Data primer untuk kajian ini diperolehi melalui borang soal selidik yang diedarkan kepada pesawah. Pegawai di KETARA membantu sebagai pembanci untuk memudahkan pengisian maklumat dalam borang soal selidik tersebut. Data yang dikumpulkan mengandungi maklumat demografi pesawah, keluasan penanaman padi dan pengeluaran, aktiviti ekonomi tambahan yang dijalankan, dan punca pendapatan.

Punca pendapatan pesawah dikategorikan kepada dua kumpulan utama iaitu aktiviti pertanian dan aktiviti bukan berasaskan pertanian. Pendapatan daripada pertanian adalah seperti (i) padi, (ii) tanaman lain (kelapa sawit, getah, pisang, fertigasi, tembikai, dan durian), dan (iii) ternakan. Kedua, pendapatan daripada aktiviti bukan berasaskan pertanian adalah seperti (i) perkhidmatan (broker mesin menanam padi, membajak, meracun, dan menyelia benih), (ii) perniagaan (kedai makan, kedai runcit, dan kontraktor), (iii) bergaji tetap (kakitangan kerajaan/organisasi), dan (iv) lain-lain seperti pemberian daripada anak-anak, elaun, bantuan kerajaan, dan pencen.

\section{Kaedah Kajian}

Analisis deskriptif dijalankan dan data dipersembahkan dalam bentuk jadual dan graf. Bagi mencapai objektif seterusnya, iaitu untuk mendapatkan tempoh masa yang diperlukan bagi pesawah keluar daripada kepompong kemiskinan, kajian ini menggunakan kaedah yang 
dicadangkan oleh Morduch (1998). Morduch telah membuat penambahbaikan kepada indeks yang telah diperkenalkan oleh Watts (1968), iaitu dengan membahagikan indeks yang dicadangkan oleh Watts (W) dengan kadar pertumbuhan pendapatan. Berikut adalah kaedah untuk mendapatkan tempoh masa tersebut.

$$
t(\gamma)=\frac{1}{n} \sum_{i=1}^{n} t_{j}(\gamma)=\frac{1}{n} \sum_{i=1}^{m} \frac{\ln (z)-\ln \left(y_{i}\right)}{\gamma}=\frac{W}{\gamma}
$$

di mana;

$z$ ialah pendapatan garis kemiskinan (PGK)

$y i$ ialah pendapatan oleh individu $i$ sehingga ke $m$

$m$ ialah senarai isi rumah yang mempunyai pendapatan di bawah PGK

$\gamma$ ialah kadar pertumbuhan pendapatan

$n$ ialah jumlah sampel

Dengan kaedah ini, dapatan kajian menjadi lebih bermakna dan keputusan kajian dengan menggunakan pendekatan ini boleh dihuraikan sebagai purata tempoh masa yang diperlukan oleh semua responden untuk keluar daripada kemiskinan dengan diberikan kadar pertumbuhan pendapatan $\gamma$.

Bagi mendapatkan purata tempoh masa yang diperlukan untuk golongan miskin sahaja untuk keluar daripada kepompong kemiskinan, ia boleh diperolehi dengan membahagikan persamaan (1) atau $t(\gamma)$ dengan kadar kemiskinan (head count ratio) seperti berikut:

$$
t^{p}(\gamma)=\frac{t(\gamma)}{P_{0}}
$$

di mana $P_{0}=$ kadar kemiskinan (headcount ratio) $=m / n$, dengan $m$ ialah jumlah bilangan isi rumah yang miskin dan $n$ ialah jumlah sampel keseluruhan.

\section{Dapatan Kajian dan Perbincangan}

Sosio-demografi

Majoriti responden (96.32\%) adalah lelaki. Dari segi kategori umur, majoriti terdiri daripada pesawah yang berumur 41 tahun atau lebih (74.50\%). Mereka yang berumur antara 51 tahun hingga 60 tahun merupakan kumpulan yang tertinggi (29.70\%). Dari segi tahap pendidikan, majoriti responden terdiri daripada mereka yang mempunyai kelulusan di peringkat sekolah menengah iaitu seramai 238 orang (67.9\%). Ringkasan maklumat demografi responden adalah seperti di Jadual 1.

Jadual 1. Ringkasan Sosio-demografi Responden

\begin{tabular}{cccc}
\hline Item & Keterangan & Bilangan & Peratus \\
\hline Jantina & Lelaki & 340 & 96.32 \\
Umur & Perempuan & 13 & 3.68 \\
& $<30$ & 34 & 9.63 \\
& $31-40$ & 55 & 15.58 \\
& $41-50$ & 83 & 23.51 \\
& $51-60$ & 111 & 31.44 \\
& $61-70$ & 57 & 16.15 \\
& $>70$ & 12 & 3.40 \\
& Tiada data & 1 & 0.28
\end{tabular}




\begin{tabular}{cccc} 
& Tidak bersekolah & 3 & 0.8 \\
Tahap & Sekolah rendah & 86 & 24.6 \\
Pendidikan & Sekolah menengah & 238 & 67.9 \\
& Sijil dan diploma & 23 & 6.6 \\
& Ijazah & 3 & 0.8 \\
\hline
\end{tabular}

Pemilikan dan Keluasan Tanah yang Diusahakan

Majoriti responden (73.3\%) menyewa tanah untuk menanam padi sama ada di tanah persendirian ataupun melalui kaedah sewaan dan pawah. Hanya 98 orang $(27.7 \%)$ memiliki tanah sendiri untuk aktiviti penanaman padi. Ini menunjukkan bahawa terdapat kemungkinan bahawa tuan tanah tidak berminat atau tidak berupaya mengusahakan tanah mereka dan menyerahkannya untuk diusahakan oleh pihak lain. Dari segi keluasan tanah yang diusahakan, sebanyak $28 \%$ responden mengusahakan tanah seluas $1-1.9$ hektar, diikuti oleh responden yang mengusahakan tanah seluas $2-2.9$ hektar (21.1\%). Secara keseluruhan, sebanyak $65.1 \%$ responden mengusahakan tanah sawah kurang daripada 2.9 hektar.

\section{Struktur Pendapatan}

Dalam analisis ini, pesawah dibahagikan kepada tiga kumpulan. Kumpulan pertama ialah pesawah dan ahli isi rumah yang mempunyai pendapatan yang berada dalam kelompok kumpulan tertinggi 20\% (T20). Kumpulan kedua ialah kumpulan pertengahan 40\% (M40) manakala kumpulan ketiga ialah kumpulan terendah 40\% (B40). Secara ringkas, berdasarkan kategori yang dikeluarkan oleh Unit Perancang Ekonomi, Kategori Tertinggi 20\% (T20) adalah mereka yang berpendapatan RM9,619 ke atas, Kategori Pendapatan Pertengahan Tinggi (M40) adalah mereka yang berpendapatan antara RM4,360 hingga RM9,619, dan Kumpulan Berpendapatan 40\% Terendah (B40) adalah mereka yang berpendapatan di bawah RM4,360.

Bagaimana angka pendapatan ini diperolehi? Ia diperolehi melalui pendapatan penengah isi rumah. Ini bermakna pelbagai pendapatan isi rumah diatur dari rendah ke tinggi, dan nilai penengah bagi setiap katogeri dicatatkan. Pendapatan penengahan digunakan kerana ia mewakili angka yang lebih tepat berbanding nombor purata. Berikut ialah huraian bagi tiga kategori pendapatan yang selalu diperkatakan di Malaysia. Huaraian ini dipetik daripada Mesyuarat Kedua, Penggal Kedua Parlimen Keempat Belas 2019 seperti berikut:

“...Kategori kumpulan pendapatan yang dikeluarkan oleh Kementerian Hal Ehwal Ekonomi (MEA) yang meliputi isi rumah B40, M40 dan T20 adalah mengguna pakai data Penyiasatan Pendapatan Isi Rumah dan Kemudahan Asas (PPIR\&KA) oleh Jabatan Perangkaan Malaysia (DOSM). Penyiasatan ini dijalankan setiap dua kali dalam tempoh lima tahun yang merangkumi data pendapatan isi rumah penengah, purata dan bilangan isi rumah dalam setiap kategori kumpulan pendapatan. MEA telah mengklasifikasikan kategori kumpulan pendapatan dan sub kumpulan pendapatan berdasarkan data tersebut. Secara umum, kategori pendapatan terbahagi kepada tiga kumpulan pendapatan utama iaitu T20, M40 dan B40. Definisi kumpulan pendapatan tersebut adalah seperti berikut: a. B40 adalah Bottom 40\% iaitu merujuk kepada kumpulan isi rumah berpendapatan 40 peratus terendah dari keseluruhan isi rumah. Berdasarkan PPIR\&KA 2016, had pendapatan isi rumah $B 40$ di peringkat nasional adalah RM4,360 yang meliputi 2.78 juta isi rumah Malaysia. 
M40 adalah Middle 40\% iaitu kumpulan isi rumah berpendapatan 40 peratus pertengahan dari keseluruhan isi rumah. Berdasarkan PPIR\&KA 2016, had pendapatan isi rumah M40 di peringkat nasional adalah tidak kurang daripada atau sama dengan RM4,360 dan tidak melebihi atau sama dengan RM9,619 yang meliputi 2.78 juta isi rumah Malaysia. T20 adalah Top 20\% iaitu kumpulan isi rumah berpendapatan 20 peratus tertinggi dari keseluruhan isi rumah. Berdasarkan PPIR\&KA2016, had pendapatan isi rumah T20 di peringkat nasional adalah melebihi RM9,619 yang meliputi 1.39 juta isi rumah Malaysia. Berdasarkan PPIR\&KA 2016, terdapat sejumlah 6.9 juta isi rumah di Malaysia. Dari segi kumpulan etnik, peratusan isi rumah Bumiputera adalah $64.5 \%$, isi rumah Cina $25.3 \%$, isi rumah India $8.9 \%$ dan lain-lain $1.9 \%$. Bagi isi rumah B40, $71.3 \%$ adalah terdiri daripada isi rumah Bumiputera, $18.7 \%$ adalah isi rumah Cina, $8.1 \%$ adalah isi rumah India dan 2.0\% lain-lain. Seterusnya, bagi isi rumah M40, 64\% adalah terdiri daripada isi rumahBumiputera, 25.5\% adalah isi rumah Cina, 9.6\% adalah isi rumah India dan 0.9\% lain-lain.Manakala bagi isi rumah T20, 52.2\% adalah terdiri daripada isi rumah Bumiputera, 38.2\% adalah isi rumah Cina, 9\% adalah isi rumah India dan 0.6\% lain-lain. 4. Mengikut negeri, Perak merupakan negeri yang mempunyai peratusan isi rumah B40 tertinggi dengan peratusan $12.5 \%$. Manakala bagi M40 dan T20, Selangor mencatatkan negeri tertinggi dengan $20.4 \%$ dan $36.8 \%$.

Kerajaan komited untuk memastikan ekonomi negara terus membangun dan berkembang dengan utuh dan kukuh. Melalui pendekatan pembangunan yang inklusif dan holisitik berasaskan "shared prosperity", Kerajaan yakin bahawa jurang ekonomi antara kaum akan dapat dirapatkan. Ini akan memastikan hasil pertumbuhan ekonomi dapat dikongsi dan dinikmati oleh seluruh rakyat dan negara akan mencapai Kemakmuran Bersama."

Berdasarkan kajian ini, terdapat seorang sahaja pesawah yang berpendapatan dalam kategori T20. Sebanyak $16.4 \%$ berpendapatan dalam kategori M40. Majoriti responden $(83.3 \%)$ memperolehi pendapatan dalam kategori B40, iaitu 56.1\% mempunyai pendapatan antara RM980 hingga RM2,614 dan $18.7 \%$ berpendapatan kurang daripada RM980. Ringkasan taburan pendapatan responden ditunjukkan di Jadual 2.

Terdapat dua kelompok pesawah iaitu mereka yang bekerja sepenuh masa sebagai pesawah dan separuh masa iaitu mereka yang mempunyai pekerjaan utama dan mengusahakan sawah secara sambilan. Antara pekerjaan utama mereka adalah polis, penolong jurutera, pembantu awam, pembantu perubatan, kakitangan awam, dan guru. Daripada keseluruhan responden, didapati bahawa seramai 270 orang (76.49\%) merupakan pesawah sepenuh masa dan 83 orang (23.51\%) merupakan pesawah separuh masa. Majoriti responden $(83 \%)$ berada dalam kelompok B40. Terdapat seramai 58 orang responden (17\%) berpendapatan dalam kategori M40. Ringkasan pecahan responden mengikut kategori pendapatan dan sepenuh atau separuh masa adalah sepeperti di Jadual 3. 
Jadual 2. Pendapatan Mengikut Kategori

\begin{tabular}{lrr}
\hline Kategori & Bil. responden & Peratus \\
\hline T20 & 1 & 0.3 \\
M40 & 58 & 16.4 \\
B40 & 294 & 83.3 \\
- Pendapatan Pertengahan Rendah (antara RM2,614 & 74 & 25.2 \\
$\quad$ - RM4,360 & 165 & 56.1 \\
- Pendapatan Rendah (antara RM980 - RM2,614) & 55 & 18.7 \\
- Miskin (kurang daripada RM980) & & \\
\hline$\quad$ Jumlah & 353 & 100 \\
\hline
\end{tabular}

Jadual 3. Pecahan Pendapatan Mengikut Kategori

\begin{tabular}{llll}
\hline Pekerjaan & Sepenuh masa & Separuh masa & Jumlah (\%) \\
\hline T20 & 1 & 0 & $1(0.3 \%)$ \\
M40 & 32 & 26 & $58(16.7 \%)$ \\
B40 & 237 & 57 & $294(83 \%)$ \\
\hline Jumlah & $270(76.49 \%)$ & $83(23.51 \%)$ & $353(100 \%)$ \\
\hline
\end{tabular}

Sumbangan Sumber Pendapatan Lain Kepada Pesawah

Kebanyakan pesawah melakukan lebih daripada satu pekerjaan. Sebanyak $47.6 \%$ melakukan dua jenis aktiviti manakala $15.0 \%$ terlibat dalam tiga aktiviti ekonomi (penanaman padi dan satu aktiviti ekonomi tambahan). Terdapat seorang sahaja pesawah dalam kelompok T20. Manakala seramai 32 orang pesawah memperolehi pendapatan dalam kategori M40. Daripada 32 orang pesawah ini, seramai 9 orang bergantung kepada pendapatan padi sahaja. Walaupun purata pengeluaran padi hanya dalam lingkungan 4 tan metrik /hektar tetapi keluasan yang diusahakan sangat mempengaruhi pulangan pendapatan. Mereka didapati mengusahakan sawah seluas 4 hingga 13 hektar iaitu melebih daripada kadar purata keluasan iaitu 2.9 hektar. Berdasarkan penemuan ini, pesawah mampu untuk berada dalam kategori M40 sekiranya mereka mengusahakan tanah yang luas. Rajah 1 menunjukkan perbezaan pendapatan seramai 23 orang pesawah yang mempunyai pendapatan padi dan pendapatan daripada aktiviti ekonomi tambahan yang lain.

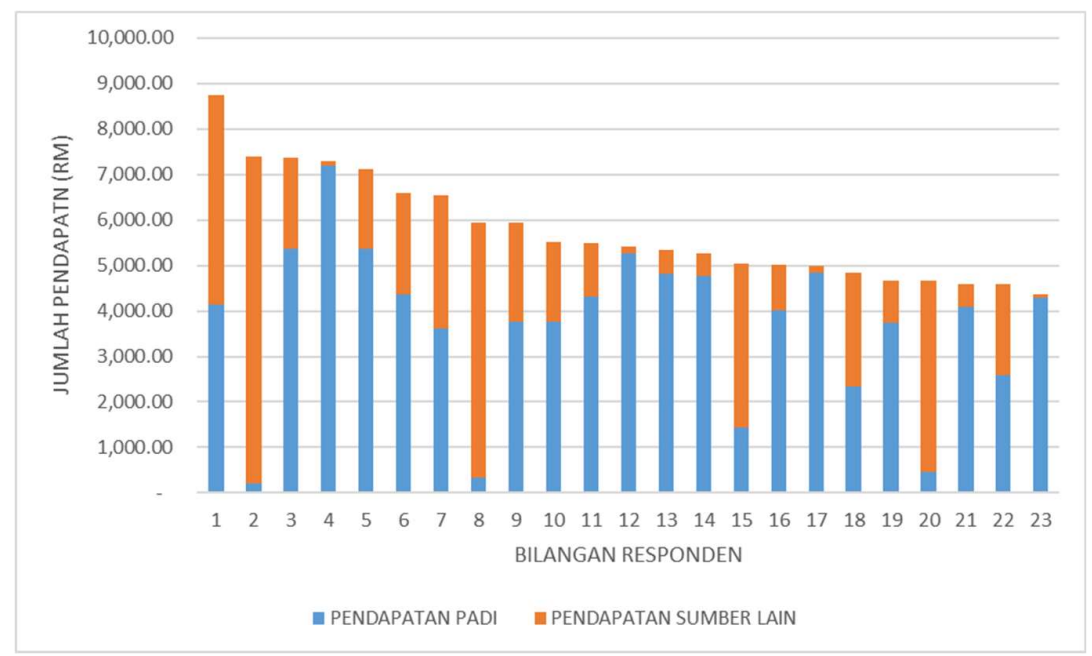

Rajah 1. Jumlah Pendapatan Padi dan Pendaatan Sumber Lain 
Secara keseluruhannya, didapati bahawa tiada aktiviti ekonomi dominan yang menyumbang kepada pesawah sama ada daripada ladang mahupun bukan berasaskan ladang. Pulangan pendapatan daripada sesuatu aktiviti berbeza-beza mengikut pesawah seperti yang ditunjukkan di Jadual 4. Sektor perkhidmatan didapati menjadi penyumbang penting kepada pendapatan pesawah. Penemuan ini selari dengan hasil kajian oleh Siti Badariah dan Mohd Rosli (2016) yang menunjukkan bahawa pendapatan daripada aktiviti bukan berasaskan ladang adalah penting bagi menghalang pesawah yang berpendapatan rendah tergolong dalam kelompok miskin.

Jadual 4. Ringkasan peratusan Sumbangan Padi dan Aktiviti Ekonomi Lain

\begin{tabular}{lcccccc}
\hline Responden & $\begin{array}{c}\text { Padi } \\
(\%)\end{array}$ & $\begin{array}{c}\text { Tanaman } \\
\text { Lain (\%) }\end{array}$ & $\begin{array}{c}\text { Ternakan } \\
(\%)\end{array}$ & $\begin{array}{c}\text { Perkhidmatan } \\
(\%)\end{array}$ & $\begin{array}{c}\text { Perniagaan } \\
(\%)\end{array}$ & $\begin{array}{c}\text { Lain-lain } \\
(\%)\end{array}$ \\
\hline 1 & 47.43 & 3.43 & - & - & 17.14 & 32.00 \\
2 & 2.67 & $\mathbf{4 3 . 2 6}$ & - & - & $\mathbf{5 4 . 0 7}$ & - \\
4 & 66.06 & 4.41 & - & 14.39 & 0.00 & 15.14 \\
5 & 55.02 & 0.38 & - & $\mathbf{4 4 . 5 9}$ & 0.00 & - \\
6 & 5.60 & 10.41 & - & $\mathbf{8 3 . 9 9}$ & 0.00 & - \\
7 & 63.54 & $\mathbf{2 1 . 0 4}$ & - & 7.00 & 0.00 & 8.42 \\
8 & 90.04 & 0.62 & - & 9.34 & 0.00 & - \\
9 & 97.00 & 1.00 & - & 2.00 & 0.00 & - \\
11 & 75.62 & 0.00 & - & 11.72 & 0.00 & 12.66 \\
12 & 68.33 & $\mathbf{2 2 . 6 2}$ & - & - & 0.00 & 9.05 \\
13 & 78.77 & 0.00 & - & $\mathbf{2 1 . 2 3}$ & 0.00 & - \\
14 & 96.92 & 0.00 & - & 3.08 & 0.00 & - \\
15 & 90.49 & 0.00 & - & 9.51 & 0.00 & - \\
16 & 80.08 & 0.00 & - & - & 19.92 & - \\
17 & 48.27 & 0.00 & - & $\mathbf{5 1 . 7 3}$ & 0.00 & - \\
21 & 98.46 & 0.00 & - & 1.54 & 0.00 & - \\
22 & 98.63 & 0.00 & - & - & 0.00 & 1.37 \\
23 & 28.54 & 0.00 & - & - & 0.00 & 71.46 \\
\hline
\end{tabular}

Nota: * Pencen, bantuan kerajaan, dan pemberian anak.

\section{Jangka Masa Keluar kemiskinan}

Jadual 5 menunjukkan purata jangka masa keluar daripada kemiskinan dengan menggunakan beberapa kemungkinan kadar pertumbuhan pendapatan $(0.01,0.03,0.05,0.07$, dan $0.10 \%)$. Purata masa untuk keluar daripada kemiskinan dikira bagi dua kumpulan pesawah: (a) kumpulan yang berpendapatan daripada sumber tanaman padi sahaja, dan (b) kumpulan yang berpendapatan daripada sumber padi dan sumber pendapatan lain. Pendapatan-pendapatan lain ini termasuklah pendapatan daripada aktiviti pertanian yang lain selain daripada padi, perkhidmatan, sumbangan anak, pencen, dan sumber pendapatan lain. Bagi membezakan antara kelompok yang miskin dengan yang tidak miskin, analisis ini menggunakan Pendapatan Garis Kemiskinan (PGK) pada nilai RM980.00.

Jika berlaku peningkatan dalam pertumbuhan pendapatan dari 1 peratus kepada 10 peratus, jangka masa purata untuk keluar daripada kemiskinan bagi kedua-dua kumpulan menunjukkan keadaan yang bertambah baik (sila rujuk Jadual 5). Yakni, purata tempoh masa yang diperlukan untuk keluar daripada kepompong kemiskinan semakin singkat. 
Jadual 5. Jangka Masa Keluar Kemiskinan

\begin{tabular}{|c|c|c|c|c|}
\hline \multirow[b]{2}{*}{$\begin{array}{l}\text { Kadar } \\
\text { pertumbuhan } \\
\text { pendapatan }(\gamma)\end{array}$} & \multicolumn{2}{|c|}{$\begin{array}{l}\text { Pendapatan Padi Sahaja } \\
P o=0.433(43.3 \%) ; m=153\end{array}$} & \multicolumn{2}{|c|}{$\begin{array}{l}\text { Jumlah Pendapatan ( Padi dan bukan padi) } \\
\mathrm{Po}=0.156(15.6 \%) ; \mathrm{m}=55\end{array}$} \\
\hline & $\begin{array}{l}\text { Jangka masa } \\
\text { keluar kemiskinan } \\
\text { bagi semua } \\
\text { responden; } \\
t \gamma\end{array}$ & $\begin{array}{l}\text { Jangkamasa } \\
\text { keluar kemiskinan } \\
\text { bagi mereka yang } \\
\text { miskin sahaja } \\
t^{p} \gamma\end{array}$ & $\begin{array}{l}\text { Jangka masa } \\
\text { keluar kemiskinan } \\
\text { bagi semua } \\
\text { responden; } \\
t \gamma\end{array}$ & $\begin{array}{l}\text { Jangkamasa keluar } \\
\text { kemiskinan bagi } \\
\text { mereka yang miskin } \\
\text { sahaja } \\
t^{p} \gamma\end{array}$ \\
\hline 0.01 & 30.55 & 70.48 & 6.09 & 39.08 \\
\hline 0.03 & 10.18 & 23.49 & 2.03 & 13.03 \\
\hline 0.05 & 6.11 & 14.10 & 1.22 & 7.82 \\
\hline 0.07 & 4.36 & 10.10 & 0.87 & 5.58 \\
\hline 0.10 & 3.05 & 7.05 & 0,61 & 3.91 \\
\hline
\end{tabular}

Nota: $\mathrm{z}=980.00 ; \mathrm{n}=353$

Yang lebih menarik ialah dapatan menunjukkan dengan jelas perbezaan antara tempoh masa purata untuk keluar daripada kemiskinan bagi pesawah yang mempunyai pendapatan padi sahaja dengan pesawah yang mempunyai pelbagai sumber pendapatan (padi dan bukan padi). Keputusan kajian menunjukkan pesawah yang melaksanakan pelbagai aktiviti ekonomi tambahan yang lain akan dapat keluar daripada kepompong kemiskinan lebih cepat berbanding pesawah yang tidak mempunyai pendapatan daripada sumber aktiviti tambahan yang lain. Sebagai contoh, jika berlakunya pertumbuhan pendapatan pesawah sebanyak $5 \%$, purata masa untuk keluar kemiskinan bagi mereka yang miskin dan yang memiliki pendapatan daripada sumber padi sahaja adalah selama 14.10 tahun. Manakala masa yang diperlukan adalah lebih pendek iaitu 7.82 tahun bagi mereka yang mempunyai sumber pendapatan padi dan bukan padi. Pesawah yang mempunyai pendapatan padi dan pendapatan bukan padi dijangka dapat menjimatkan masa untuk keluar daripada kemiskinan selama 6.28 tahun (14.10 tahun tolak 7.82 tahun) berbanding dengan mereka yang tidak mempunyai sumber pendapatan lain. Cuba bayangkan sekiranya pertumbuhan pendapatan berlaku dengan sangat kecil sekali, iaitu katakan pada kadar satu peratus. Pesawah yang mempunyai pendapatan padi sahaka perlu mengambil masa selama 70.48 tahun untuk keluar daripada kemiskinan. Namun tempoh masa ini dapat dipendekkan selama lebih kurang 31.4 tahun (70.48 tahun tolak 39.08 tahun) jika mereka mempunyai aktiviti pendapatan lain selain pendapatan padi.

\section{Implikasi Dasar dan Kesimpulan}

Pelbagai usaha boleh dilakukan untuk memajukan sektor pertanian dan industri asas tani agar sektor ini menjadi sektor yang moden dan berdaya saing. Peranan pihak Kementerian Pertanian dan sektor swasta seperti menjalankan penyelidikan dan pembangunan (R\&D) adalah amat penting. Institut Penyelidikan dan Kemajuan Pertanian Malaysia (MARDI) sewajarnya menawarkan bengkel atau kursus untuk memberikan khidmat nasihat serta membekalkan baka benih yang bermutu kepada petani dengan menggunakan bioteknologi yang canggih. Jurusan Pertanian di pusat-pusat pengajian tinggi (IPT) dan pakar pertanian perlu komited dalam mengkaji penggunaan ilmu sains dan teknologi dalam sektor pertanian dan industri asas tani. Selain itu, modal juga memainkan peranan penting dalam membantu petani padi untuk meningkatkan pendapatan mereka sama ada dalam meningkatkan aktiviti ekonomi hiliran yang berkaitan dengan hasil padi mahu pun untuk melakukan aktiviti bukan pertanian yang lain. Modal atau sumber kewangan memainkan peranan penting bagi menjalankan pertanian secara komersial. Mungkin pihak yang bertanggungjawab boleh memberikan pinjaman melalui skim pinjaman berkadar faedah rendah dan melonggarkan syarat kepada pihak petani yang bercadang untuk menjalankan perniagaan ataupun aktiviti yang boleh menjana pendapatan. 
Dengan bantuan atau pinjaman ini, pesawah atau petani dapat membeli mesin yang canggih dan bahan racun serangga serta baja kimia untuk menjalankan pertanian mereka.

Kajian ini juga mendapati bahawa sebanyak $64.6 \%$ pesawah mempunyai aktiviti lain untuk menyokong pendapatan mereka. Tiada aktiviti ekonomi yang benar-benar dominan. Oleh itu, model aktiviti ekonomi tambahan yang berjaya perlu dikenal pasti untuk dijadikan pakej bagi memastikan setiap pelaburan yang dibuat terhadap aktiviti tertentu benar-benar memberikan pulangan yang baik kepada pesawah. Ini selari dengan penyataan oleh Alam (2010) yang menyatakan bahawa fokus perlu diberikan kepada bidang ekonomi yang berpotensi bagi membasmi kemiskinan. Keterlibatan dalam aktiviti bukan pertanian juga membantu dalam memendekkan tempoh masa untuk keluar daripada kepompong kemiskinan. Antara bidang yang berpotensi bagi pesawah terlibat ialah pelancongan atau pelancongan tani (agrotourism) dan aktiviti rantaian lain yang berkaitan dengan penanaman padi. Kenyataan ini disokong oleh Neda Tiraieyari dan Azimi Hamzah (2011) yang menyatakan bahawa ramai petani pada zaman ini memilih industri pelancongan tani untuk menjana pendapatan tambahan melalui aktiviti pertanian tradisional mereka. Dengan adanya daya tarikan semula jadi, produk pertanian yang pelbagai serta kebudayaan yang tersendiri maka Malaysia mempunyai potensi besar untuk membangunkan industri pelancongan tani ini. 


\section{Rujukan}

Ahmad Zubir, I., \& Chamsuri, S. (2012). Kawasan pengairan muda: merentasi masa menyangga keselamatan makanan negara. Jurnal Pengurusan Awam. Diambil daripada www.myjurnal.my/filebank/published article/25909/Article 7.ODF

Barrett, C.B, Reardon. T. \& Webb, P. (2001). Nonfarm income diversification and householdlivelihood strategies in rural Africa: Concepts, dynamics and policy implications. Food Policy, 25, 315-331

Corner,L. (1981). The impact of rural outmigration: Labour supply and cultivation techniques in a double cropped padi area, West Malaysia. Unpublished PhD dissertation, Macquarie University, Sydney

De Janvry, A, Sadoulet dan Zhu (2005) De Janvry, A., Sadoulet, E., \& Zhu, N. The role of non-farm income in reducing rural poverty and inequality in China, 2005. Working Paper No 1001.Department of Agricultural \& Resource Economics, UC Berkeley.

De Janvry, A. (1981). The agrarian question and reformism in Latin America. Baltimore: John Hopkins University Press.

Department of Statictic (DOS). Household Income and Basic Amenities Survey Report. Diambil dari https:/www.dosm.gov.my/v1/index.php? $\mathrm{r}=$ column/ctheme ByCat\&cat=120\&bul_id=RUZ5REwveU1ra1hGL21JWV1PRmU2Zz09\&menu_id=a mVoWU54UT10a21NWmdhMjFMMWcyZz09

Farah Hanim, A.R., Nurul Nazihah, H. \& Norhaslinda, Z.A. (2017). Supply and demand of rice in Malaysia: A system dynamics approach. International Journal of Supply Chain Management, 6, 234-240.

Fields, G. S. (1994). Data for measuring poverty and inequality changes in the developing policies in the Harris-Todaro Model. Journal of Development Economics, $76(1), 127-46$.

Food and Agriculture Organizations of the United Nations (FAO). (2011). Economic and social perspectives. The Rice Crisis: Market, Policies and Security. 2010. Edited by David Dawe. www.fao.org/3/a-an794e.pdf

Heyer,J dan I. Campbell. (1999). The effects of famine on capital assets in South West Ethiopia, 1984-1993. Report to the Department for International Development Economic and Social Committee on Overseas Research (DFID-ESCOR), University of Oxford.

Karp, I. (2007). Income distribution and the allocation of public agricultural investment in developing countries. Background paper for the WDR 2008. Washington DC: The World Bank. Quoted in The World Bank, 2008, 209

Kementerian Pertanian dan Industri Asas Tani (MOA). (2018). Perangkaan Agromakanan 2017. Diambil dari http:/www.moa.gov.my/ documents/20182/29034/ Perangkaan+ Agromakanan+2017-ilovepdf-compressed.pdf/14f6dd00-f2a1-414b-98a3$251 \mathrm{ef} 670 \mathrm{~d} 7 \mathrm{fc}$

Khazanah Research Institute (KRI). (2019). The Status of The Paddy and Rice Industry in Malaysia. http://www.krinstitute.org/assets/xxxcontentMS/img/template/editor/20190409 Rice Report Full\%20Report Final.pdf

Lanjouw, P. (2000). Rural non-agricultural employment and poverty in Latin America: evidence from Ecuador and El Salvador. In López R. and A. Valdés (eds.). Rural poverty in Latin America. London: Macmillan Press, 2000.

Lanjouw, J.O. \& Lanjouw, P. (2001). The rural non-farm sector: issues and evidence from developing countries. Agricultural Economics. 26, 1-23 
Lanjouw, P. (1998). Ecuador's rural nonfarm sector as a route out of poverty. World Bank Policy Research Working Paper 1904.Washington, DC: World Bank.

Mesyuarat Kedua, Penggal Kedua parlimen Keempat Belas 201922 Julai Hingga 31 Julai 2019 soalan No. 1 Hingga 174. Online Malaysia Parliament Report, https:/www.parlimen.gov.my/files/jindex/pdf/JDN22HINGGA31JULAI2019.pdf. Capaian 3 september 2019.

Mohd Rashid, R., \& Mohd Dainuri, M.S. (2013). Food and livelihood security of the Malaysian Paddy Farmers. Economic and Technology Management Review, 8, 59-69 .

Morduch, J. (1998). Poverty, economic growth, and average exit time. Economics Letters, 59, 385-390

Neda, T. \& Azimi, H. (2011). Agri-tourism: Potential opportunities for farmers and local communities in Malaysia. African Journal of Agricultural Research, 7 (31), 4357-4361.

Norsida, M; Sayiya, \& S.I. (2009). Off-Farm Employment Participation Among Paddy Farmers in The Muda Agricultural Development Authority and Kemasin Semerak Granary Areas of Malaysia. Asia-Pacific Development Journal, 16 (2), 141-153.

Radin Firdaus, R.B., Ahmad Zubir, I., Chamhuri, S., \& Abdul Hamid, J. (2014). Penghidupan petani padi dalam mendepani cabaran perubahan iklim: Peranan intervensi kerajaan menerusi sistem subsidi harga padi (SSHP). Kajian Malaysia, 32 (2), 73-92.

Shand, R.T. (1987). Malaysia income distribution in a dynamic rural sector: Some evidence from Malaysia. Economic Development and Cultural Change, 36 (1), 35-50.

Shand, R.T. \& Chew, T. A. (1983). Off-farm employment in the Kemubu Project in Kelantan, Malaysia. Paper presented at a Conference in Chiang-Mai, Thailand, 2326August.http://www.cababstractsplus.org/abstracts/Abstract.aspx?AcNo=198767044 59 (accessed 12 May 2010)

Siti Badariah, S.N. \& Mohd Rosli, M. (2016). Distributional Effects of Non-farm incomes in Malaysia Rice Bowl. International Journal of Social Economics, 43(2), 205-220.

Siti Hadijah Che Mat \& Roslan Abdul Hakim. (2010) Kesan pendapatan bukan pertanian ke atas krmidkinsn: kajian kes petani di Kedah. Jurnal Ekonomi Malaysia, 44, 101-107.

Siti Hadijah Che Mat, Ahmad Zafarullah Abdul Jalil. \& Mukaramah Harun. (2012). Non-farm income and income inequality in rural Kedah. International Review of Business Research Papers, 8(2), 1-11

Siti Hadijah Che Mat, Nor'Aznin Abu Bakar and Ahmad Zafarullah Abdul Jalil. (2012). Pendapatan bukan pertanian dan sumbangannya dalam memendekkan tempoh masa keluar daripada kepompong kemiskinan. Kajian Malaysia, 30(2), 121-141.

Watts, H. W. (1968). An economic definition of poverty. In On understanding poverty, ed. D. Moynihan, 316-329. New York: Basic Books.

World Development Report. (2008). World development report 2008. Agriculture for development. Washington DC: The World Bank 